\title{
KUALITAS AIR PERMUKAAN DAN SEBARAN SEDIMEN DASAR PERAIRAN SEDANAU, NATUNA, KEPULAUAN RIAU
}

\author{
Yusmiana Puspitaningsih Rahayu1), Rizky Anggoro Adi²), Dino Gunawan Priyambodo"1), \\ Candra Dwi Puspita1) \& Hariyanto Triwibowo')
}

\author{
1)Puslitbang Sumber Daya Laut dan Pesisir-KKP \\ 2)Loka Penelitian Sumber Daya dan Kerentanan Pesisir, Bungus-KKP
}

Diterima tanggal: 29 Januari 2016; Diterima setelah perbaikan: 26 Februari 2016; Disetujui terbit tanggal 7 Maret 2016

\begin{abstract}
ABSTRAK
Penelitian ini bertujuan untuk mengkaji kondisi kualitas air dan sedimen dasar perairan perairan Sedanau, Natuna yang banyak dijadikan sebagai lokasi budi daya perairan. Penelitian dilakukan pada Juli 2010 dengan melakukan pengukuran parameter kualitas air in situ $(\mathrm{pH}$, oksigen terlarut, salinitas,suhu, kecerahan) dan pengambilan sampel sedimen di 43 titik sampling. Sebanyak 18 sampel air dan 18 sampel sedimen kemudian dibawa ke laboratorium untuk dianalisis lebih lanjut. Hasil penelitian menunjukkan bahwa jenis sedimen yang terdapat di lokasi penelitian adalah pasir, pasir lanauan dan lanau pasiran. Kondisi kualitas air di daerah penelitian masih dalam kondisi baik bagi kelangsungan kegiatan budidaya kecuali kandungan $\mathrm{Pb}$ dalam air laut di lokasi antara Pulau Sedanau dan Pulau Tiga yang melampaui baku mutu. Kandungan logam berat Cd dan As yang terkandung dalam sedimen di lokasi penelitian pada beberapa titik perlu diwaspadai dan dilakukan penelitian lebih lanjut guna memonitor kesesuaian lingkungan bagi kegiatan budi daya.
\end{abstract}

Kata kunci: kualitas air, sebaran sedimen, budi daya, Natuna.

\section{ABSTRACT}

The aim of this study was to assess water quality and sediment distribution of Sedanau water, Natuna. The study was conducted in July 2010 to measure water quality parameters ( $\mathrm{pH}$, dissolved oxygen, salinity, temperature, and transparency) and sediment sampling in 43 sampling points. A total of 18 water samples and 18 sediment samples were analyzed in the laboratory for heavy metals and other parameters analysis. The results show that sediment types in the study site were sand, silty sand and sandy silt. Water quality conditions in the study site were still met the national quality standards and were suitable for aquaculture activities except for $\mathrm{Pb}$ content in the sea water that exceed the standard. The content of $\mathrm{Cd}$ and $\mathrm{As}$ in the sediments at some points need to be monitored to maintain the suitability for aquaculture activities.

Keywords: water quality, sediment distribution, aquaculture, Natuna.

\section{PENDAHULUAN}

Kepulauan Natuna di Provinsi Kepulauan Riau merupakan salah satu kepulauan terdepan di Indonesia yang berbatasan langsung dengan beberapa negara tetangga. Terletak di Laut Cina Selatan, kepulauan ini merupakan kawasan yang memiliki kekayaan sumberdaya alam sangat tinggi. Lautnya terkenal sebagai penghasil minyak dan gas bumi, kekayaan komoditas biota lautnya pun bernilai ekonomis sangat tinggi. Pemanfaatan sumber daya perikanan di wilayah Natuna dilakukan dengan cara usaha penangkapan dan budidaya komoditas perikanan.

Budi daya perikanan umumnya dapat dijumpai pada perairan yang relatif tenang, terlindung dari arus dan gelombang yang besar. Salah satu lokasi yang banyak terdapat usaha budi daya perikanan oleh masyarakat adalah di perairan sekitar Pulau Sedanau. Pulau ini merupakan pulau kecil yang sebagian besar masyarakatnya berprofesi sebagai nelayan dan pembudidaya keramba jaring tancap dan jaring apung.

Lokasi penelitian berada pada Kawasan KKLD (Kawasan Konservasi Laut Daerah) I, dimana kawasan tersebut diprioritaskan untuk mendukung kegiatan perikanan berkelanjutan. Pengertian zona perikanan berkelanjutan menurut Peraturan Menteri Kelautan dan Perikanan No. 10 Tahun 2010 adalah kawasan yang memiliki nilai konservasi tetapi masih dapat bertoleransi dengan pemanfaatan yang ramah lingkungan (Republik Indonesia, 2010).

Penelitian mengenai kondisi perairan diperlukan guna menjaga keberlanjutan kegiatan budidaya. Pengetahuan mengenai karakteristik sedimen juga sangat penting karena masing-masing biota memerlukan kondisi substrat yang berbeda untuk kesesuaian hidupnya, seperti misalnya rumput laut gracilaria yang idealnya memerlukan pasir berlumpur sebagai habitat hidupnya sedangkan teripang memerlukan kondisi dasar perairan landai dan berpasir. Kondisi substrat dasar yang sesuai akan menentukan tingkat keberhasilan suatu usaha budi daya perairan.

Tujuan penelitian ini adalah untuk mengetahui kondisi kualitas air dan sebaran sedimen dasar perairan guna mendukung kegiatan budi daya perikanan laut di Perairan Sedanau, Natuna, Provinsi Kepulauan Riau. 


\section{METODE PENELITIAN}

Penelitian dilakukan pada Juli 2010 di sekitar Perairan Sedanau, Natuna, Provinsi Kepulauan Riau. Peta lokasi penelitian dapat dilihat pada Gambar 1. Pengambilan sampel dilakukan pada 43 titik sampling dari sekitar Sedanau hingga ke selatan, yaitu perairan Pulau Tiga (P. Kumbik, P. Sebangmawang dan P. Kumang).

Data primer diperoleh dengan melakukan pengukuran kualitas air dan analisis karakteristik sedimen permukaan dasar di lokasi penelitian. Pengukuran kualitas air dilakukan secara in situ di 43 titik sampling menggunakan alat pengukuran kualitas air portable yaitu Water Quality Checker TOA DKK untuk parameter suhu, derajat keasaman $(\mathrm{pH})$, oksigen terlarut (DO) dan salinitas. Pengukuran dilakukan pada permukaan laut (kedalaman sekitar 1 meter). Pengukuran kecerahan dilakukan menggunakan pinggan hitam putih atau secchi disk pada keseluruhan titik sampling (43 titik).
Sampel air diambil di 18 titik sampling yang dianggap mewakili seluruh lokasi penelitian dengan menggunakan Nansen Water Sampler dan disimpan dalam botol plastik.

Sampel kemudian disimpan dalam kondisi dingin selama survei dan pengangkutan ke laboratorium untuk dianalisis lebih lanjut. Pengambilan sampel sedimen dilakukan dengan menggunakan grab sampler pada 43 titik sampling yang sama, kemudian sedimen dimasukkan ke dalam plastik segel dan diberi label untuk selanjutnya dianalisa pengujian besar butir dan kandungan logam beratnya.

Analisis kualitas air ex situ dilakukan di Laboratorium Produktivitas dan Lingkungan Perairan (ProLing), Fakultas Perikanan dan IImu Kelautan, Institut Pertanian Bogor (IPB). Parameter yang diamati adalah $\mathrm{Hg}, \mathrm{Pb}, \mathrm{NH}_{3}-\mathrm{N}$, dan TSS. Pengukuran sampel air dilakukan berdasarkan metode gravimetri sesuai dengan American Public Health Association (APHA) $21^{\text {st }}$ edition (APHA, 2005). Analisis sebaran sedimen mengacu pada metode analisis besar butir yang

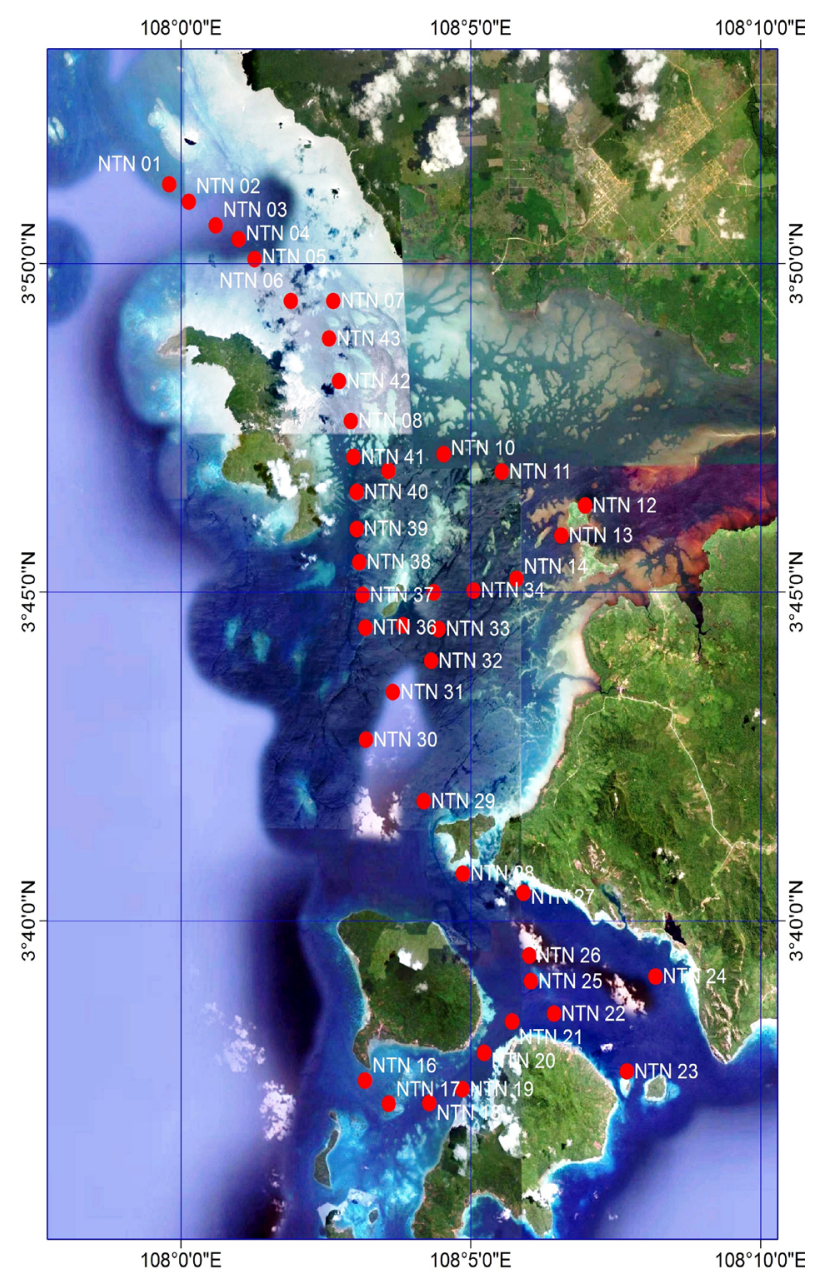

Gambar 1. Lokasi Penelitian. 
kemudian diklasifikasi menurut Folk (1980). Analisis logam berat pada sampel sedimen dilakukan di laboratorium Pusat Penelitian Geologi Laut (PPGL), Bandung terhadap 18 sampel yang dianggap mewakili. Parameter yang diamati adalah $\mathrm{Cd}$, As dan $\mathrm{Hg}$ dengan mengacu pada metode APHA $21^{\text {st }}$ edition.

Interpretasi data dilakukan secara deskriptif untuk mengetahui dan mendapatkan gambaran mengenai kondisi kualitas perairan Sedanau dengan membandingkan hasil pengukuran dan baku mutu kualitas air laut untuk biota laut sesuai Keputusan Menteri Lingkungan Hidup Nomor 51 Tahun 2004 (Republik Indonesia, 2004).

\section{HASIL DAN PEMBAHASAN}

Pengukuran kualitas air di Perairan Sedanau menunjukkan hasil sebagai berikut:

\section{Kecerahan}

Kecerahan air merupakan ukuran kejernihan suatu perairan, semakin tinggi suatu kecerahan perairan, semakin dalam cahaya menembus ke dalam air. Kecerahan menentukan ketebalan lapisan produktif. Berkurangnya kecerahan air akan mengurangi kemampuan fotosintesis tumbuhan air, selain itu dapat pula mempengaruhi kegiatan fisiologi biota air (Effendi, 2003).

Pengukuran menunjukkan angka kecerahan di Perairan Sedanau berkisar antara 3,0 - 10,5 m. Sebaran kecerahan di lokasi penelitian dapat dilihat pada Gambar 2.

Kecerahan merupakan ukuran transparansi perairan, yang ditemukan secara visual dengan menggunakan secchi disk. Nilai kecerahan dinyatakan dalam satuan meter, nilai ini sangat dipengaruhi oleh keadaan cuaca, waktu pengukuran, kekeruhan dan padatan tersuspensi Angka baku mutu untuk budidaya perikanan laut, kecerahan air yang dipersyaratkan adalah > 3 m (Republik Indonesia, 2004; Akbar \& Sudaryanto, 2001).

Gambar 2 menunjukkan bahwa nilai rata-rata distribusi kecerahan di atas $3 \mathrm{~m}$ dan semakin tinggi nilainya ke arah selatan yaitu di sekitar perairan Pulau Tiga. Kondisi kecerahan di lokasi penelitian masih memenuhi syarat sesuai dengan Keputusan Menteri Negara Lingkungan Hidup No. 51 Tahun 2004 dimana kecerahan yang baik untuk biota laut harus lebih besar dari 3 meter.

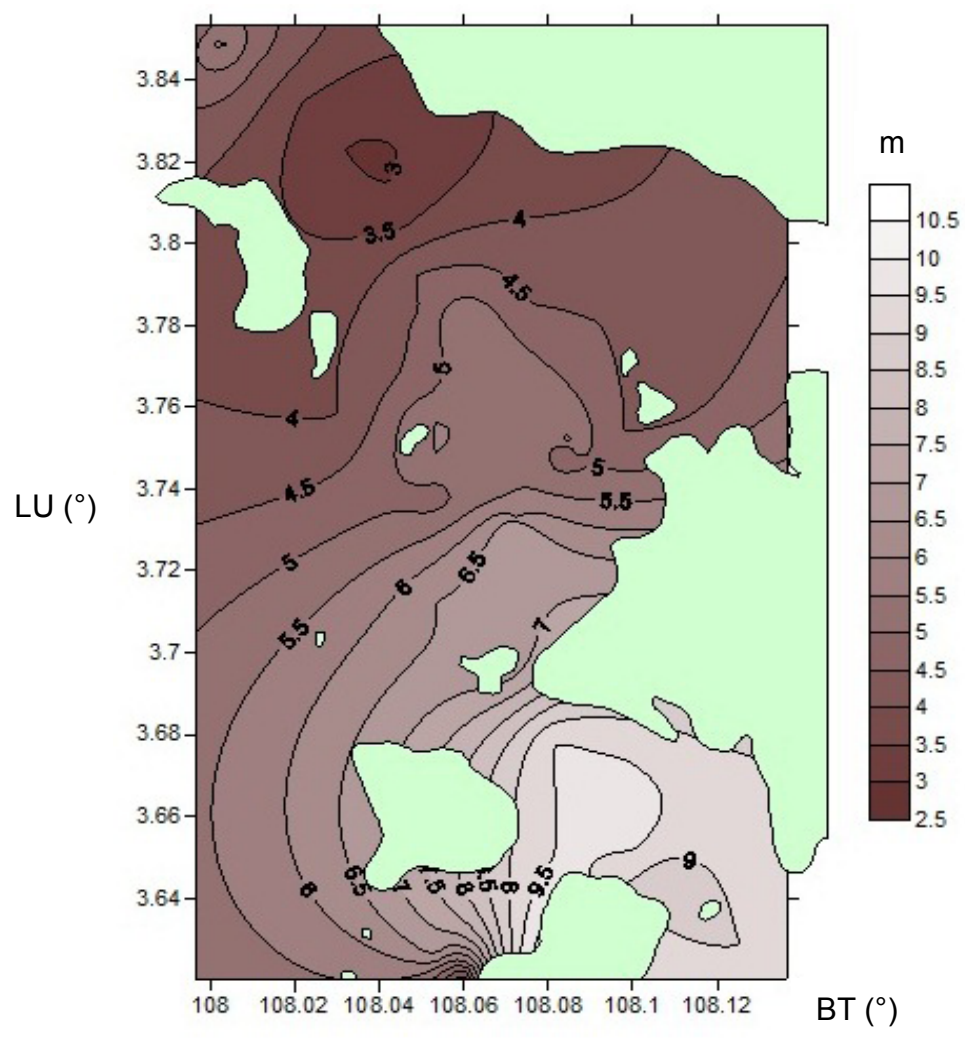

Gambar 2. Peta Sebaran Kecerahan Daerah Penelitian. 


\section{pH (Derajat Keasaman)}

Air laut normal selalu bersifat basa, dan kondisi demikian diperlukan bagi kehidupan biota laut.

Hasil pengukuran $\mathrm{pH}$ menunjukkan angka antara 7,32 - 8,18. $\mathrm{pH}$ air laut permukaan di Indonesia umumnya bervariasi antara $6.0-8,5$. Perubahan $\mathrm{pH}$ sedikit saja dari $\mathrm{pH}$ alami akan memberikan petunjuk terganggunya sistem penyangga. Hal ini dapat menimbulkan perubahan dan ketidakseimbangan kadar $\mathrm{CO} 2$ yang dapat membahayakan kehidupan biota laut.

Sebaran nilai pH dapat dilihat pada Gambar 3. Sesuai dengan Keputusan Menteri Negara Lingkungan Hidup Nomor 51 Tahun 2004, nilai pH yang baik bagi biota laut adalah 7-8,5. Nilai pH di lokasi penelitian masih dalam kondisi yang baik, dengan sebaran nilai $\mathrm{pH}$ makin kecil ke arah muara sungai yang disebabkan oleh percampuran air dari sungai.

\section{DO (Dissolved Oxygen)}

Hasil pengukuran DO menunjukkan kisaran antara $6,93-7,88 \mathrm{mg} / \mathrm{l}$. Sebaran nilai DO di lokasi penelitian dapat dilihat pada Gambar 4.
DO merupakan faktor pembatas bagi kehidupan organisme. Perubahan konsentrasi oksigen terlarut dapat menimbulkan efek langsung yang berakibat pada kematian organisme perairan. Pengaruh tidak langsungnya yaitu meningkatkan toksisitas bahan pencemar yang pada akhirnya dapat membahayakan organisme itu sendiri (Rahayu, 1991).

Kandungan DO dalam perairan turut menentukan kualitas perairan, karena oksigen sangat dibutuhkan untuk pernapasan (respirasi) makhluk hidup dan untuk proses oksidasi dalam perairan. Fungsi lain dari oksigen adalah sebagai oksidator senyawa-senyawa kimia di perairan (CRITC-COREMAP, 2004).

Keputusan Menteri Negara Lingkungan Hidup Nomor 51 Tahun 2004 menyebutkan bahwa nilai baku mutu DO untuk biota laut yaitu $>5 \mathrm{mg} / \mathrm{l}$. Hasil pengukuran di lokasi penelitian menunjukkan bahwa kandungan DO masih dalam ambang batas yang memenuhi baku mutu untuk biota laut.

\section{Salinitas}

Salinitas mempunyai peran yang penting dan memiliki ikatan erat dengan kehidupan organisme perairan termasuk ikan, dimana secara fisiologis

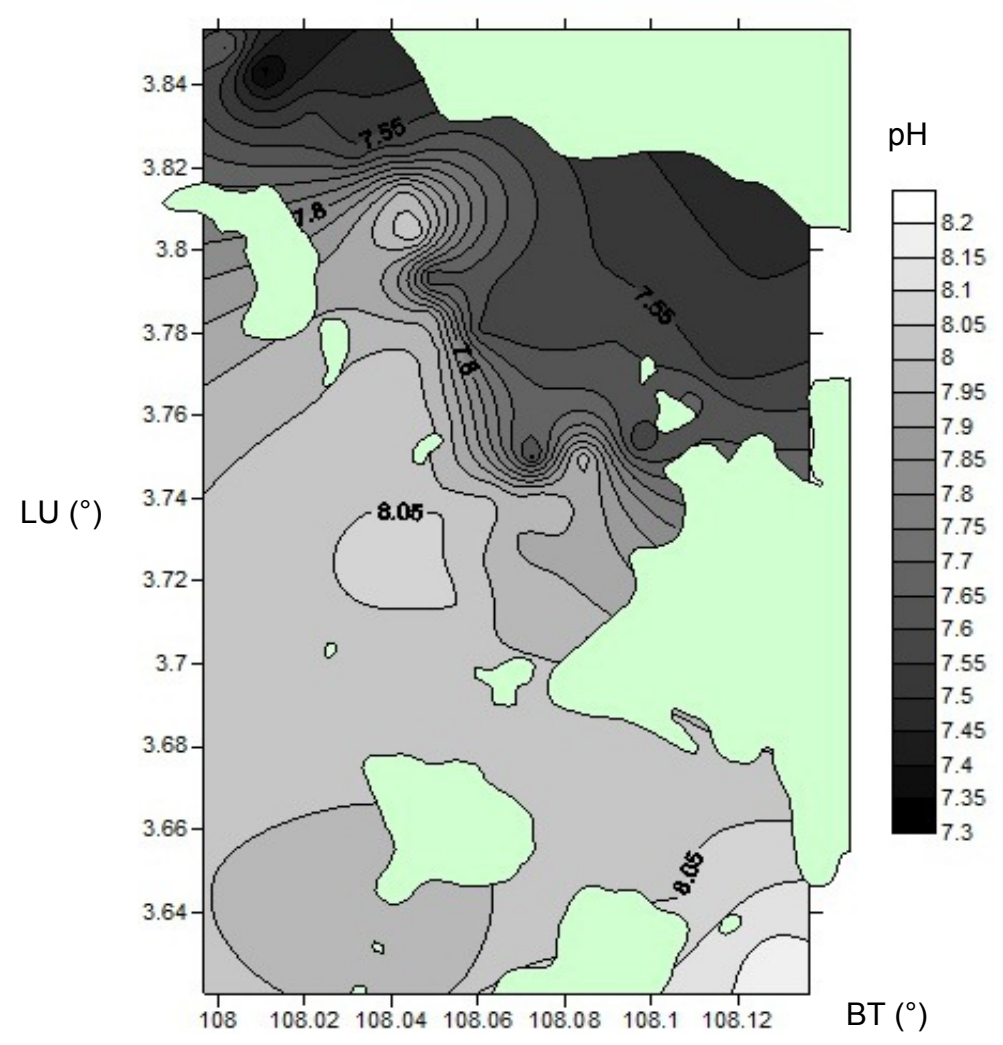

Gambar 3. Peta Sebaran pH Daerah Penelitian. 


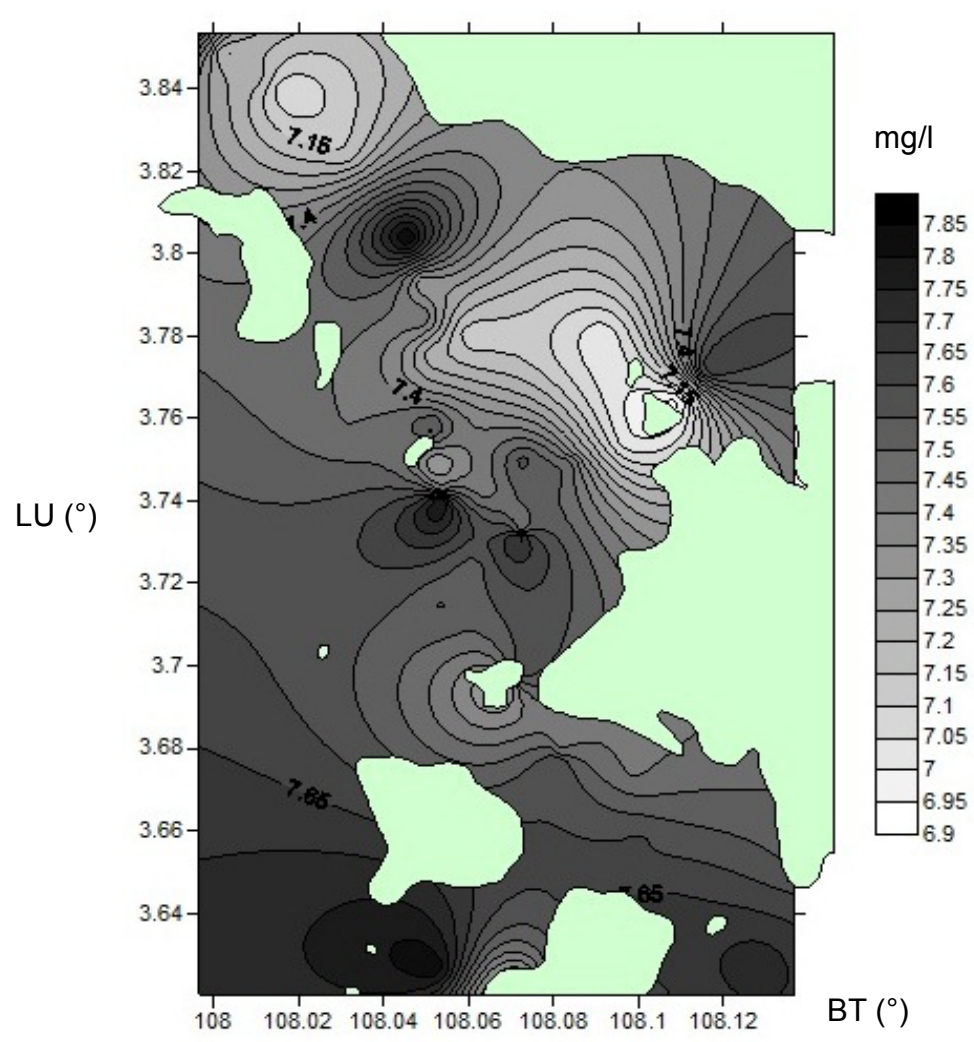

Gambar 4. Peta Sebaran DO Daerah Penelitian.

salinitas sangat mempengaruhi penyesuaian tekanan osmotik ikan tersebut.

Hasil pengukuran salinitas perairan menunjukkan kisaran antara 25,9 - 30,9 PSU. Sebaran nilai salinitas dapat dilihat pada Gambar 5.

Sebaran salinitas di laut dipengaruhi oleh beberapa faktor seperti pola sirkulasi air, penguapan, curah hujan, dan aliran air sungai.

Hasil pengukuran salinitas menunjukkan kisaran antara 25,9 - 30,9 PSU. Sesuai dengan Keputusan Menteri Negara Lingkungan Hidup Nomor 51 Tahun 2004 yang menyatakan bahwa baku mutu salinitas untuk biota laut adalah sampai dengan 34 PSU maka salinitas di lokasi penelitian masih tergolong baik bagi biota laut.

Sebaran salinitas (Gambar 5) menunjukkan bahwa semakin ke arah Pulau Tiga, angka salinitas semakin besar. Nilai salinitas terendah terlihat di sekitar muara Sungai Binjai dikarenakan banyaknya air sungai yang masuk ke laut.

\section{Suhu}

Hasil pengukuran suhu perairan menunjukkan kisaran antara $29,10-31,40{ }^{\circ} \mathrm{C}$. Suhu dapat mempengaruhi fotosintesis di laut baik secara langsung maupun tidak langsung. Pengaruh secara langsung yakni suhu berperan untuk mengontrol reaksi kimia enzimatik dalam proses fotosintesis. Suhu air yang layak untuk budidaya ikan laut adalah $27-32^{\circ} \mathrm{C}$ (Mayunar \& Imanto, 1995).

Kenaikan suhu perairan akan menurunkan kelarutan oksigen dalam air, memberikan pengaruh langsung terhadap aktivitas ikan serta dapat menaikkan daya racun suatu polutan terhadap organisme perairan (Brown, 1980).

Dibandingkan dengan baku mutu menurut Keputusan Menteri Negara Lingkungan Hidup Nomor 51 Tahun 2004 yang mensyaratkan baku mutu suhu air laut bagi biota laut sebesar $28^{\circ} \mathrm{C}-32^{\circ} \mathrm{C}$, maka suhu perairan di lokasi penelitian masih dalam batas yang baik bagi biota laut. 


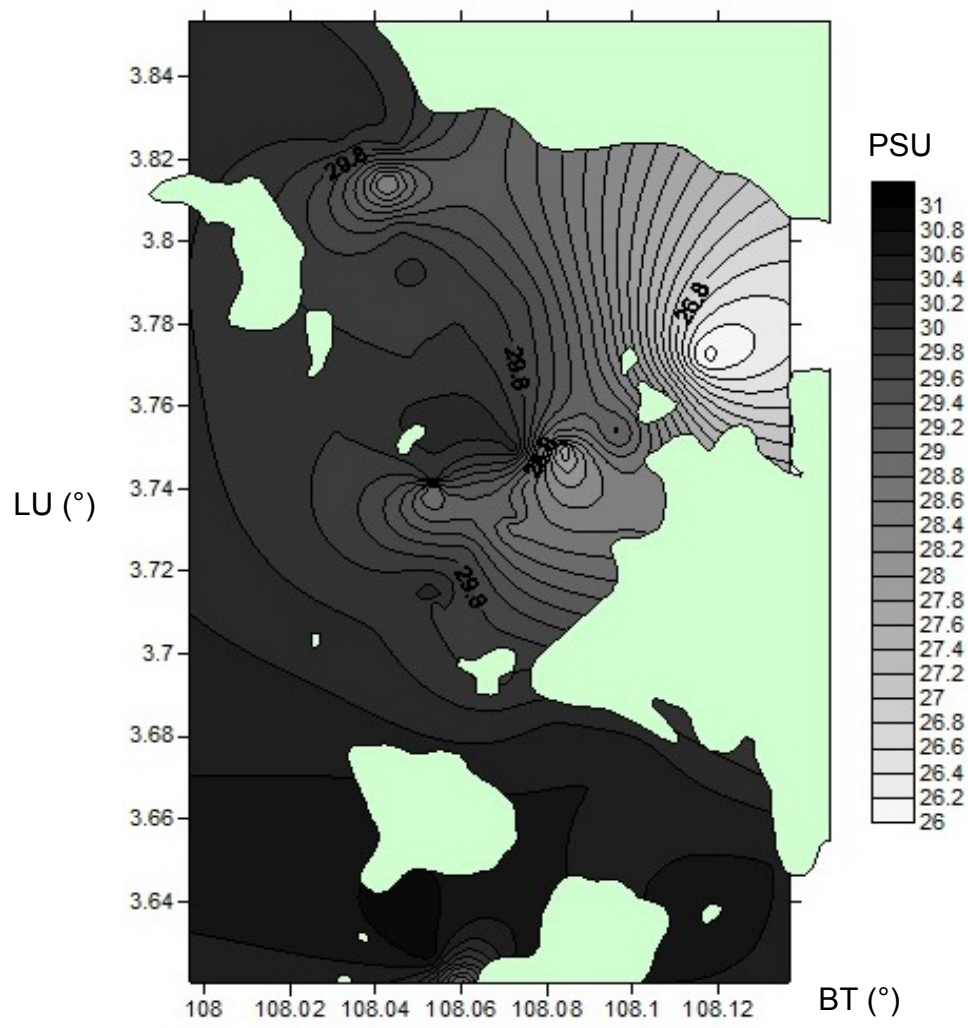

Gambar 5. Peta Sebaran Salinitas Daerah Penelitian.

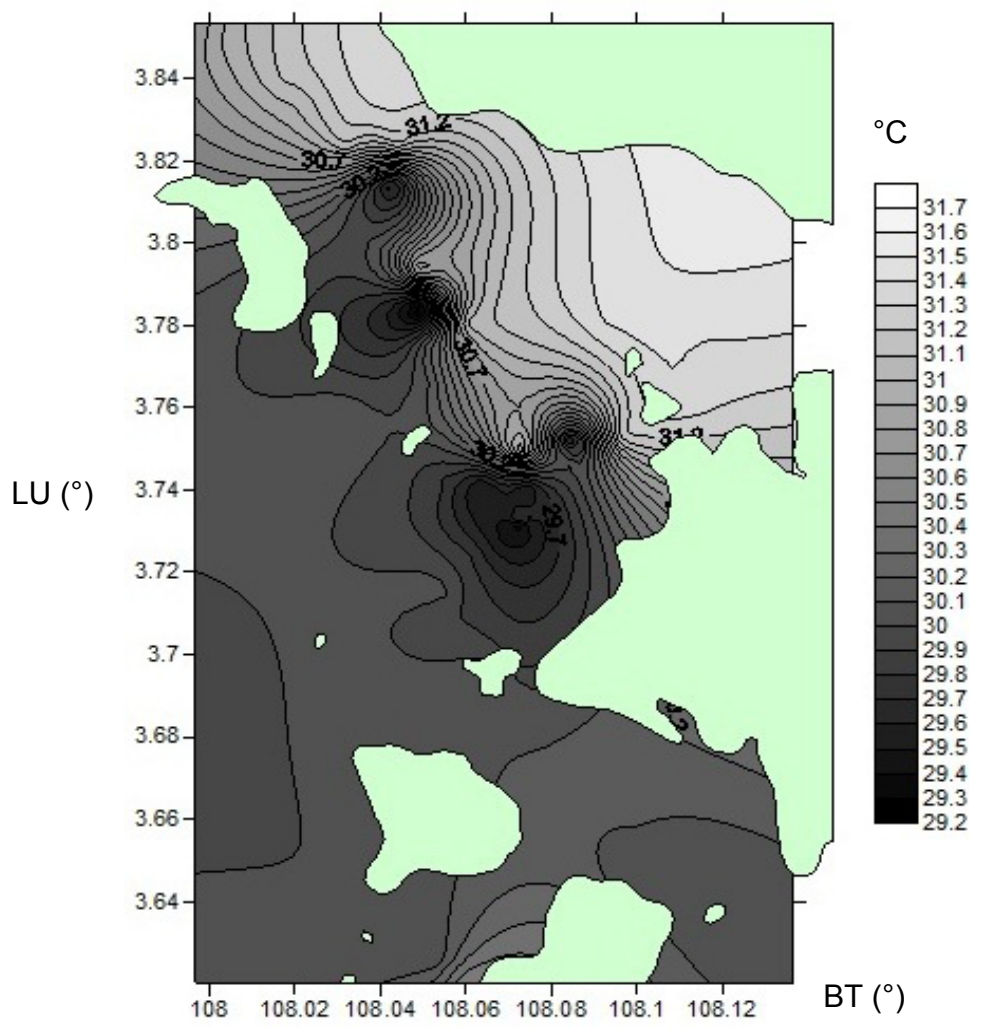

Gambar 6. Peta Sebaran Suhu Daerah Penelitian. 
Kandungan $\mathrm{Hg}$ (Raksa), $\mathrm{Pb}$ (Timbal), $\quad \mathrm{NH}_{3}-\mathrm{N}$ (Ammonia total), dan TSS (Total Suspended Solid) dalam Air

Hasil analisis kandungan $\mathrm{Hg}, \mathrm{Pb}, \mathrm{NH}_{3}-\mathrm{N}$, dan TSS dalam air disajikan dalam Tabel 1. Lokasi titik sampling dapat dilihat pada Gambar 1.

Konsentrasi bahan pencemar yang masuk ke perairan bisa mempengaruhi kehidupan organisme laut. Salah satu jenis unsur kimia yang bisa menyebabkan terjadi kerusakan ekosistem perairan adalah unsur logam berat. Sebagaimana diketahui unsur logam berat yang masuk ke perairan berasal dari berbagai kegiatan industri selain bersumber dari alam sendiri. Logam berat yang dilimpahkan ke perairan, baik di sungai ataupun laut akan dipindahkan dari badan air melalui beberapa proses yaitu pengendapan, adsorbsi dan absorbsi oleh organisme perairan.

Hasil analisis laboratorium untuk pengujian sampel air (Tabel 1) menunjukkan bahwa kandungan $\mathrm{Hg}$ dalam setiap sampel sebesar $<0,0002 \mathrm{mg} / \mathrm{l}$, nilai ini masih memenuhi baku mutu air laut dimana batasnya adalah $0,001 \mathrm{mg} / \mathrm{l}$. Kandungan $\mathrm{Pb}$ berkisar antara $0,006 \mathrm{mg} / \mathrm{l}-0,038 \mathrm{mg} / \mathrm{l}$ sedangkan baku mutunya yaitu sebesar $0,008 \mathrm{mg} / \mathrm{l}$. Hal ini mengindikasikan bahwa sebagian besar lokasi memiliki kandungan $\mathrm{Pb}$ yang melampaui batas baku mutu. Tingginya kandungan $\mathrm{Pb}$ di beberapa lokasi pengambilan sampel diduga disebabkan oleh buangan hasil pembakaran bahan bakar minyak (BBM) oleh kapal-kapal yang melalui perairan sekitar lokasi penelitian. Sebagaimana yang dinyatakan oleh Clark (1996) bahwa logam berat timbal yang terkandung dalam bahan bakar sebagai anti pemecah minyak (seperti $P b$ tetraethyl dan tetramethyl) dilepaskan ke atmosfer melalui alat pembuangan asap, kemudian terlarut dalam air laut.

Hasil penelitian Sagala et al. (2014) yang melakukan penelitian terhadap kandungan logam berat dalam air di Perairan Natuna pada 2012 menunjukkan kadar $\mathrm{Pb}$ yang masih memenuhi baku mutu yaitu $<0,005 \mathrm{mg} / \mathrm{l}$. Perbedaan kadar ini menunjukkan bahwa tingginya kandungan $\mathrm{Pb}$ dalam penelitian ini bersifat tidak permanen. Hal ini dimungkinkan karena adanya pergerakan air yang sangat dipengaruhi oleh angin, gelombang, dan arus perairan sehingga senantiasa terjadi pengadukan dan perpindahan massa air berikut bahan-bahan yang terkandung di dalamnya (Amin, 2011).

Kandungan $\mathrm{NH}_{3}-\mathrm{N}$ dari hasil analisis yaitu $<0,020$ $\mathrm{mg} / \mathrm{l}$. Ammonia adalah salah satu senyawa toksin dalam perairan. Kadar ammonia dalam air laut sangat bervariasi dan dapat berubah secara cepat. Ammonia dapat bersifat toksik bagi biota jika kadarnya melebihi ambang batas maksimum. Meningkatnya kadar ammonia di laut berkaitan erat dengan masuknya bahan organik yang mudah terurai, baik yang mengandung unsur nitrogen maupun tidak. Penguraian bahan organik yang mengandung unsur nitrogen akan menghasilkan senyawa nitrat $\left(\mathrm{NO}_{3}\right)$, nitrit $\left(\mathrm{NO}_{2}\right)$ dan selanjutnya menjadi ammonia $\left(\mathrm{NH}_{3}\right)$ (Effendi, 2003). Ambang batas baku mutu ammonia total bagi biota laut adalah sebesar $0,3 \mathrm{mg} / \mathrm{l}$, sehingga kandungan $\mathrm{NH}_{3}-\mathrm{N}$ di Perairan Sedanau masih memenuhi baku mutu.

Tabel 1.

Kandungan $\mathrm{Hg}, \mathrm{Pb}, \mathrm{NH}_{3}-\mathrm{N}$, dan TSS dalam Air

\begin{tabular}{llllll}
\hline No & Lokasi & $\mathrm{Hg}(\mathrm{mg} / \mathrm{l})$ & $\mathrm{Pb}(\mathrm{mg} / \mathrm{l})$ & $\mathrm{NH}-\mathrm{N}(\mathrm{mg} / \mathrm{l})$ & $\mathrm{TSS}(\mathrm{mg} / \mathrm{l})$ \\
\hline 1 & NTN 01 & $<0,0002$ & 0,006 & $<0,020$ & 8 \\
2 & NTN 03 & $<0,0002$ & 0,007 & $<0,020$ & 8 \\
3 & NTN 06 & $<0,0002$ & 0,006 & $<0,020$ & 8 \\
4 & NTN 08 & $<0,0002$ & 0,016 & $<0,020$ & 11 \\
5 & NTN 10 & $<0,0002$ & 0,015 & $<0,020$ & 12 \\
6 & NTN 12 & $<0,0002$ & 0,016 & $<0,020$ & 9 \\
7 & NTN 13 & $<0,0002$ & 0,022 & $<0,020$ & 8 \\
8 & NTN 15 & $<0,0002$ & 0,018 & $<0,020$ & 8 \\
9 & NTN 16 & $<0,0002$ & 0,035 & $<0,020$ & 8 \\
10 & NTN 21 & $<0,0002$ & 0,035 & $<0,020$ & 8 \\
11 & NTN 23 & $<0,0002$ & 0,035 & $<0,020$ & 8 \\
12 & NTN 24 & $<0,0002$ & 0,036 & $<0,020$ & 9 \\
13 & NTN 27 & $<0,0002$ & 0,036 & $<0,020$ & 8 \\
14 & NTN 29 & $<0,0002$ & 0,036 & $<0,020$ & 12 \\
15 & NTN 30 & $<0,0002$ & 0,037 & $<0,020$ & 9 \\
16 & NTN 31 & $<0,0002$ & 0,038 & $<0,020$ & 8 \\
17 & NTN 36 & $<0,0002$ & 0,038 & $<0,020$ & 8020 \\
18 & NTN 39 & $<0,0002$ & 0,015 & $<0,020$ & \\
\hline
\end{tabular}


TSS adalah bahan-bahan tersuspensi (diameter $>1 \mu \mathrm{m}$ ) yang tertahan pada saringan millipore dengan diameter pori 0,45 $\mu \mathrm{m}$. TSS terdiri atas lumpur dan pasir halus serta jasad-jasad renik, yang terutama disebabkan oleh kikisan tanah atau erosi tanah yang terbawa ke badan air (Effendi, 2003).

Nilai TSS pada lokasi penelitian berkisar antara 8-12 mg/l. Menurut Keputusan Menteri Negara Lingkungan Hidup Nomor 51 Tahun 2004, nilai TSS yang baik bagi biota laut yaitu kurang dari $20 \mathrm{mg} / \mathrm{l}$, dengan demikian nilai TSS di lokasi penelitian masih dalam kategori yang baik bagi kegiatan budi daya.

\section{Sedimen Dasar Perairan Sedanau}

Hasil analisis ukuran butir pada sedimen di Perairan Sedanau disajikan dalam Tabel 2.

Hasil analisis ukuran butir sedimen yang disajikan dalam Tabel 2 memperlihatkan bahwa sedimen di Perairan Sedanau terdiri dari tiga jenis yaitu Pasir Lanauan, Lanau Pasiran dan Pasir. Peta sebaran sedimen dapat dilihat pada Gambar 7. Jenis sedimen pasir banyak dijumpai di sebelah selatan Pulau Sedanau, yaitu di sekitar Pulau Tiga. Pasir lanauan terdapat di sekitar Pulau Sedanau hingga ke arah

Tabel 2. Jenis Sedimen di Perairan Sedanau, Natuna

\begin{tabular}{|c|c|c|c|c|}
\hline No & Stasiun & Lintang & Bujur & Nama Sedimen \\
\hline 1 & NTN 01 & $3.85345 \mathrm{U}$ & 107.99667 T & Pasir Lanauan \\
\hline 2 & NTN 02 & $3.84897 \mathrm{U}$ & $108.00236 \mathrm{~T}$ & Pasir Lanauan \\
\hline 3 & NTN 03 & $3.84304 \mathrm{U}$ & $108.01009 \mathrm{~T}$ & Pasir Lanauan \\
\hline 4 & NTN 04 & $3.83947 \mathrm{U}$ & 108.01661 T & Pasir Lanauan \\
\hline 5 & NTN 05 & $3.83446 \mathrm{U}$ & 108.02127 T & Pasir Lanauan \\
\hline 6 & NTN 06 & $3.82384 \mathrm{U}$ & $108.03164 \mathrm{~T}$ & Pasir Lanauan \\
\hline 7 & NTN 07 & $3.82384 \mathrm{U}$ & $108.04384 \mathrm{~T}$ & Pasir Lanauan \\
\hline 8 & NTN 08 & $3.79343 \mathrm{U}$ & $108.04892 \mathrm{~T}$ & Pasir Lanauan \\
\hline 9 & NTN 09 & $3.78073 \mathrm{U}$ & $108.05970 \mathrm{~T}$ & Pasir Lanauan \\
\hline 10 & NTN 10 & $3.78504 \mathrm{U}$ & $108.07556 \mathrm{~T}$ & Lanau Pasiran \\
\hline 11 & NTN 11 & $3.78054 \mathrm{U}$ & 108.09224 T & Lanau Pasiran \\
\hline 12 & NTN 12 & $3.77196 \mathrm{U}$ & $108.11623 \mathrm{~T}$ & Lanau Pasiran \\
\hline 13 & NTN 13 & $3.76435 \mathrm{U}$ & 108.10939 T & Lanau Pasiran \\
\hline 14 & NTN 14 & $3.75340 \mathrm{U}$ & $108.09651 \mathrm{~T}$ & Lanau Pasiran \\
\hline 15 & NTN 15 & $3.74996 \mathrm{U}$ & $108.07271 \mathrm{~T}$ & Pasir Lanauan \\
\hline 16 & NTN 16 & $3.62623 \mathrm{U}$ & $108.05296 \mathrm{~T}$ & Pasir \\
\hline 17 & NTN 17 & $3.62028 \mathrm{U}$ & 108.05979 T & Pasir \\
\hline 18 & NTN 18 & $3.62052 \mathrm{U}$ & $108.07141 \mathrm{~T}$ & Pasir \\
\hline 19 & NTN 19 & $3.62396 \mathrm{U}$ & $108.08093 \mathrm{~T}$ & Pasir \\
\hline 20 & NTN 20 & $3.63323 \mathrm{U}$ & $108.08720 \mathrm{~T}$ & Pasir \\
\hline 21 & NTN 21 & $3.64113 \mathrm{U}$ & 108.09520 T & Pasir \\
\hline 22 & NTN 22 & $3.64318 \mathrm{U}$ & 108.10728 T & Pasir \\
\hline 23 & NTN 23 & $3.62850 \mathrm{U}$ & 108.12817 T & Pasir \\
\hline 24 & NTN 24 & $3.65261 \mathrm{U}$ & 108.13643 T & Pasir \\
\hline 25 & NTN 25 & $3.65136 \mathrm{U}$ & 108.10061 T & Pasir \\
\hline 26 & NTN 26 & $3.65794 \mathrm{U}$ & $108.10020 \mathrm{~T}$ & Pasir \\
\hline 27 & NTN 27 & $3.67384 \mathrm{U}$ & $108.09853 \mathrm{~T}$ & Pasir \\
\hline 28 & NTN 28 & $3.67872 \mathrm{U}$ & $108.08107 \mathrm{~T}$ & Pasir \\
\hline 29 & NTN 29 & $3.69699 \mathrm{U}$ & $108.06981 \mathrm{~T}$ & Pasir Lanauan \\
\hline 30 & NTN 30 & $3.71259 \mathrm{U}$ & $108.05325 \mathrm{~T}$ & Pasir Lanauan \\
\hline 31 & NTN 31 & $3.72466 \mathrm{U}$ & $108.06101 \mathrm{~T}$ & Pasir Lanauan \\
\hline 32 & NTN 32 & $3.73258 \mathrm{U}$ & 108.07198 T & Pasir Lanauan \\
\hline 33 & NTN 33 & $3.74069 \mathrm{U}$ & $108.07410 \mathrm{~T}$ & Pasir Lanauan \\
\hline 34 & NTN 34 & $3.75046 \mathrm{U}$ & $108.08414 \mathrm{~T}$ & Pasir Lanauan \\
\hline 35 & NTN 35 & $3.74170 \mathrm{U}$ & $108.06379 \mathrm{~T}$ & Pasir Lanauan \\
\hline 36 & NTN 36 & $3.74103 \mathrm{U}$ & $108.05308 \mathrm{~T}$ & Pasir Lanauan \\
\hline 37 & NTN 37 & $3.74929 \mathrm{U}$ & $108.05222 \mathrm{~T}$ & Pasir Lanauan \\
\hline 38 & NTN 38 & $3.75763 \mathrm{U}$ & $108.05128 \mathrm{~T}$ & Lanau Pasiran \\
\hline 39 & NTN 39 & $3.76602 \mathrm{U}$ & $108.05051 \mathrm{~T}$ & Lanau Pasiran \\
\hline 40 & NTN 40 & $3.77540 \mathrm{U}$ & $108.05052 \mathrm{~T}$ & Lanau Pasiran \\
\hline 41 & NTN 41 & $3.78422 \mathrm{U}$ & 108.04967 T & Pasir Lanauan \\
\hline 42 & NTN 42 & $3.80351 \mathrm{U}$ & $108.04552 \mathrm{~T}$ & Pasir Lanauan \\
\hline 43 & NTN 43 & $3.81428 \mathrm{U}$ & $108.04263 \mathrm{~T}$ & Pasir Lanauan \\
\hline
\end{tabular}




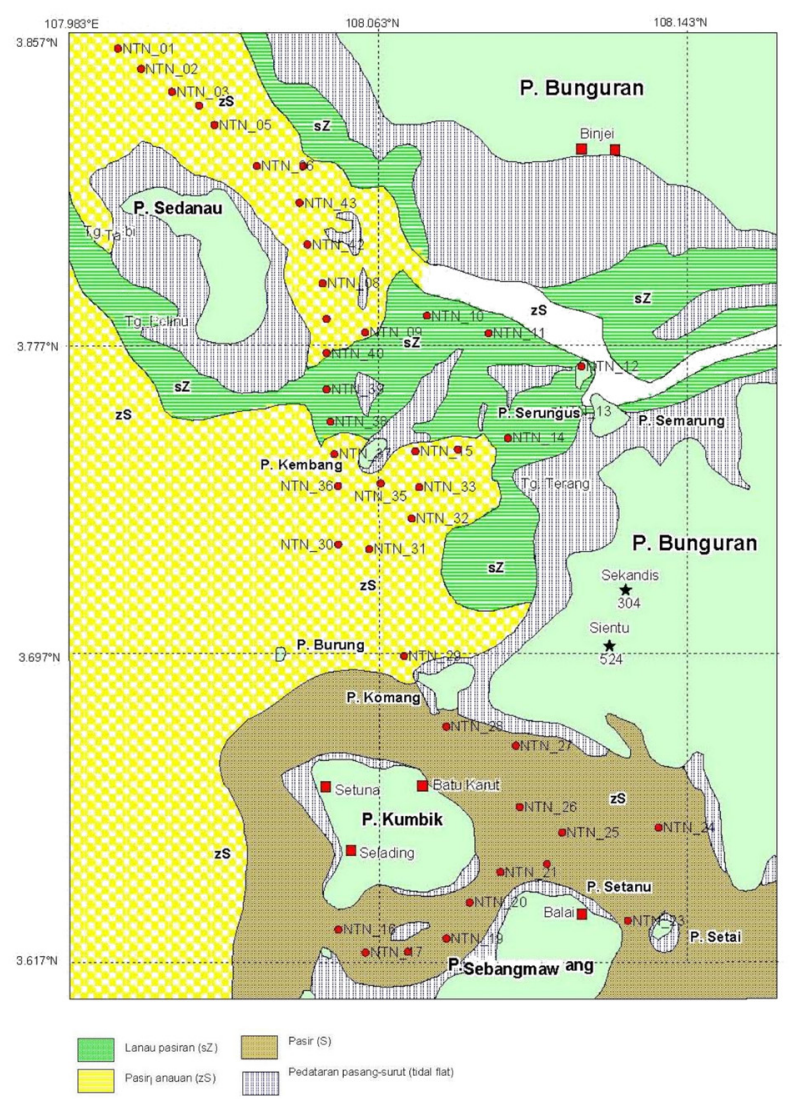

Gambar 7. Peta sebaran sedimen Perairan Sedanau.

selatan (Pulau Tiga), sedangkan lanau pasiran banyak terdapat di perairan yang mengarah ke daratan. Hal ini meunjukkan bahwa pengaruh masukan dari daratan yang terbawa melalui sungai mempengaruhi jenis sedimen dasar perairan, dimana lumpur yang diangkut ke perairan akan mengendap tidak jauh dari sungai.

Rahayu et al. (2010) menyatakan bahwa aktivitas budi daya yang banyak dilakukan di sekitar Perairan Sedanau adalah budidaya ikan kerapu dan ikan napoleon dalam keramba jaring tancap dan keramba jaring apung. Menurut Radiarta et al. (2003), substrat yang cocok untuk budidaya kerapu dan napoleon adalah substrat berpasir dan pecahan karang. Dengan demikian, kondisi sedimen di Perairan Sedanau termasuk cocok untuk mendukung kegiatan budidaya komoditas unggulan di daerah tersebut.

\section{Logam Berat dalam Sedimen}

Peningkatan kadar logam berat pada air laut akan mengakibatkan logam berat yang semula dibutuhkan untuk berbagai proses metabolisme (logam esensial) dapat berubah menjadi racun bagi organisme laut. Selain bersifat racun, logam berat di perairan juga akan terakumulasi dalam sedimen yang pada gilirannya juga dapat terakumulasi oleh organisme (Amin et al., 2011). Tabel 3 menunjukkan hasil analisis kandungan logam berat dalam sedimen di Perairan Sedanau.
Kandungan $\mathrm{Cd}$, As dan $\mathrm{Hg}$ berturut-turut adalah sebesar 5-12 ppm, <2-80 ppm dan 4-24 ppb. Baku mutu logam berat di dalam lumpur atau sedimen digunakan acuan baku mutu yang dikeluarkan oleh IADC/CEDA (1997) mengenai kandungan logam yang dapat ditoleransi keberadaannya dalam sedimen, seperti ditunjukkan dalam Tabel 4.

Hasil analisis di laboratorium untuk logam berat yang terkandung dalam sedimen apabila dibandingkan dengan Tabel 4 maka terlihat bahwa kandungan $\mathrm{Cd}$ pada sampel sedimen di daerah penelitian mayoritas berada pada nilai antara level tes dan level intervensi, yaitu dengan konsentrasi $\mathrm{Cd}$ sebesar 8 ppm-12 ppm. Hanya tiga titik sampling yang berada pada kisaran antara level limit dan level tes, yaitu dengan konsentrasi $\mathrm{Cd}$ sebesar $5 \mathrm{ppm}$. Nilai tersebut masih berada di bawah level bahaya (30 ppm), namun demikian diperlukan penelitian lebih mendalam dan kewaspadaan akan kadar $\mathrm{Cd}$ yang berada pada level tes dan level intervensi ini. Monitoring juga perlu dilakukan sehingga konsentrasi $\mathrm{Cd}$ tidak mengganggu kegiatan budidaya yang telah berlangsung di Perairan Sedanau dan tidak membahayakan manusia yang mengkonsumsi ikan hasil budidaya perairan tersebut.

Konsentrasi $\mathrm{Hg}$ dari hasil analisis laboratorium dari 18 sampel berkisar antara 4 ppb-24 ppb $(0,004$ ppm - 0,024 ppm). Nilai ini masih lebih kecil dari level 
Tabel 3. KandunganLogam Berat dalam Sedimen

\begin{tabular}{lllll}
\hline No & Stasiun & Cd (ppm) & As (ppm) & $\mathrm{Hg}(\mathrm{ppb})$ \\
\hline 1 & NTN 02 & 10 & 4 & 4 \\
2 & NTN 03 & 11 & 80 & 6,5 \\
3 & NTN 05 & 5 & $<2$ & 5 \\
4 & NTN 06 & 5 & $<2$ & 4 \\
5 & NTN 09 & 8 & $<2$ & 4 \\
6 & NTN 10 & 11 & $<2$ & 4 \\
7 & NTN 11 & 10 & 10 & 6 \\
8 & NTN 12 & 10 & 16 & 24 \\
9 & NTN 13 & 10 & 8 & 10 \\
10 & NTN 14 & 10 & 6 & 17 \\
11 & NTN 15 & 11 & 4 & 14 \\
12 & NTN 33 & 10 & $<2$ & 11 \\
13 & NTN 36 & 11 & $<2$ & 10 \\
14 & NTN 37 & 12 & 4 & 11 \\
15 & NTN 38 & 12 & $<2$ & 10 \\
16 & NTN 39 & 11 & 6 & 5 \\
17 & NTN 40 & 10 & $<2$ & 6,5 \\
18 & NTN 43 & 5 & $<2$ & 4
\end{tabular}

Tabel 4.

Kategori Tingkat Batasan Kandungan Logam Berat dalam Sedimen (IADC/CEDA, 1997)

\begin{tabular}{llllll}
\hline Logam berat & $\begin{array}{l}\text { Level } \\
\text { Target } \\
(\mathrm{ppm})\end{array}$ & $\begin{array}{l}\text { Level } \\
\text { Limit } \\
(\mathrm{ppm})\end{array}$ & $\begin{array}{l}\text { Level } \\
(\mathrm{ppm})\end{array}$ & $\begin{array}{l}\text { Level } \\
\text { intervensi } \\
(\mathrm{ppm})\end{array}$ & $\begin{array}{l}\text { Level } \\
\text { bahaya } \\
(\mathrm{ppm})\end{array}$ \\
\hline Cadmium $(\mathrm{Cd})$ & 0,8 & 2 & 7,5 & 12 & 30 \\
Merkuri $(\mathrm{Hg})$ & 0,3 & 0,5 & 1,6 & 10 & 15 \\
\hline
\end{tabular}

target, sehingga kandungan $\mathrm{Hg}$ pada sedimen di lokasi penelitian masih terbilang aman bagi biota perairan.

Konsentrasi As yang diperbolehkan dalam sedimen menurut ASEAN Marine Water Quality Management Guidelines and Monitoring (2008) yaitu sebesar 50-300 ppm. Hasil analisis menunjukkan bahwa dari 18 sampel terdapat satu sampel yaitu NTN 03 yang memiliki kandungan As tertinggi sebesar 80 ppm. Posisi lokasi stasiun NTN 03 yang dekat dengan Pulau Bunguran menyebabkan banyaknya intervensi daratan yang masuk ke perairan. Tingginya konsentrasi As pada di lokasi ini diduga karena adanya pengaruh dari aktivitas penambangan pasir di sekitar Pulau Bunguran. Selain itu kontaminasi As juga diduga bersumber dari proses alami geologi serta buangan kegiatan peternakan, industri dan pertanian (Patel et al., 2010) yang mungkin banyak terdapat di Pulau Bunguran.

\section{KESIMPULAN}

Dari hasil penelitian ini dapat disimpulkan bahwa:
1. Jenis sedimen di lokasi penelitian adalah pasir, pasir lanauan dan lanau pasiran yang termasuk cocok untuk budidaya kerapu dan napoleon sebagai komoditas unggulan di Natuna.

2. Kualitas air di Perairan Sedanau masih dalam kondisi baik bagi kelangsungan kegiatan budidaya perikanan laut, kecuali kandungan $\mathrm{Pb}$ dalam air laut di lokasi antara Pulau Sedanau dan Pulau Tiga yang melampaui baku mutu air laut untuk biota laut.

3. Kandungan logam berat $\mathrm{Cd}$ dan As yang terkandung dalam sedimen pada beberapa titik perlu diwaspadai agar tidak melewati baku mutu.

\section{Saran}

1. Perlu dilakukan monitoring yang kontinyu sehingga kadar logam berat baik dalam air maupun sedimen tidak menjadi lebih tinggi dan membahayakan bagi kegiatan budidaya di Perairan Sedanau.

2. Diperlukan pembatasan yang jelas untuk alur perlayaran kapal dan lokasi budi daya sehingga 
apabila terjadi kontaminasi bahan bakar kapal tidak membahayakan budidaya perairan laut.

\section{PERSANTUNAN}

Penulis mengucapkan terima kasih kepada Prof. Dr. Gadis Sri Haryani, DEA yang telah membimbing selama penulisan karya tulis ilmiah ini. Terima kasih juga ditujukan kepada Tim Penelitian Natuna 2010 (Rizki Anggoro Adi, Dino Gunawan Pryambodo, Hariyanto Triwibowo dan Candra Dwi Puspita). Kegiatan penelitian dilaksanakan dengan dana APBN DIPA T.A. 2010 Pusat Riset Wilayah Laut dan Sumber Daya Non Hayati, Badan Riset Kelautan dan Perikanan, Kementerian Kelautan dan Perikanan.

\section{DAFTAR PUSTAKA}

Akbar, S \& Sudaryanto, (2001). Pembenihan dan Pembesaran Kerapu Bebek. Jakarta: Penebar Swadaya.

American Public Health Association (APHA). (2005). Standard methods for the examination of water and wastewater. American Public Health Association, American Water Works Association, and Water Pollution Control Federation. 21st edition. Washington D.C. 1368p.

Amin, B., E. Afriyani \& M.A. Saputra. (2011). Distribusi Spasial Logam $\mathrm{Pb}$ dan $\mathrm{Cu}$ pada Sedimen dan Air Laut Permukaan di Perairan Tanjung Buton Kabupaten Siak Provinsi Riau. J. Teknobiologi, 2(1):1-8.

ASEAN Secretariat. (2008). ASEAN Marine Water Quality Management Guidelines and Monitoring Manual 1st Edition. Jakarta. Indonesia.

Brown, E.E \& Gratzek, J.B. (1980). Fish Farming Handbook. AVI Publishing Company, Connecticut.

Clark, J. R. (1996). Coastal Zone Management Handbook. Lewis/CRC Press, Boca Raton, Florida.

CRITC-COREMAP. (2004). Studi Baseline Ekologi Kabupaten Nauna. COREMAP-LIPI. Jakarta. 103hlm.

Effendi, H. (2003). Telaah Kualitas Air : bagi Pengelolaan Sumberdaya dan Lingkungan Perairan. Fakultas Perikanan. Bogor.

Folk, R.L. (1980). Petrology of Sedimentary Rocks. Hamphill Publishing Company Austin. Texas. $170 p$.

IADC/CEDA. (1997). Environmental aspects of dredging - conventions, codes and conditions: marine disposal. International Association of Dredging Companies (IADC), \& Central Dredging Association (CEDA), Netherlands, 1-71.

Mayunar, Purba. R \& Imanto P. T. (1995). Pemilihan Lokasi untuk Budidaya Ikan Laut. Prosiding Temu Usaha Pemasyarakatan Teknologi Keramba Jaring Apung bagi Budidaya Laut. Pusat Penelitian dan Pengembangan Perikanan. Kerjasama antara Badan Penelitian dan Pengembangan Pertanian - Forum Komunikasi Penelitian dan Pengembangan Agribisnis (FKKPA). Jakarta 12 13 April, No. 38: 179 - 187.

Patel, K. S, A. Shivras, R. Baghel, W. Corns, B. Chen, A. Raab, J. Feldmann \& B. Blazhev. (2010). Arsenic Exposure and Skin Lesions in Central India. In: Jean, Bundschuh and Bhattacharya (Eds): Arsenic in Geoshpere and Human Diseases. Taylor and Francis Group. London.

Radiarta, I. N., S. E. Wardoyo., B. Priyono \& Praseno. O. (2003). Aplikasi Sistem Informasi Geografis untuk Penentuan Lokasi Pengembangan Budidaya Laut di Teluk Ekas, Nusa Tenggara Barat. Jurnal Penelitian Perikanan Indonesia. Pusat Riset Perikanan Budidaya Jakarta. Vol 9(1): hal 67 - 71

Rahayu, S. (1991). Penelitian Kadar Oksigen Terlarut (DO) dalam Air bagi Kehidupan Ikan. BPPT No. XLV/1991. Jakarta.

Rahayu, Y.P., R.A. Adi, D.G. Pryambodo, H. Triwibowo \& Puspita, C.D. (2010). Riset Karakteristik Sedimen Permukaan Dasar Pesisir Natuna untuk Mendukung Budidaya Laut. Laporan Teknis, Pusat Riset Wilayah Laut dan Sumber Daya Non Hayati, Badan Riset Kelautan dan Perikanan, Kementerian Kelautan dan Perikanan, Jakarta.

Republik Indonesia, (2004). Keputusan Menteri Negara Lingkungan Hidup Nomor 51 tahun 2004 tentang Baku Mutu Air Laut. Jakarta: Menteri Negara Lingkungan Hidup.

Republik Indonesia, (2010). Peraturan Menteri Kelautan dan Perikanan No. 10 Tahun 2010 tentang Rencana Pengelolaan dan Zonasi Kawasan Konservasi Perairan. Jakarta: Menteri Kelautan dan Perikanan Republik Indonesia.

Sagala, S. L, R. Bramawanto, A.R.T.D. Kuswardani \& Pranowo, W. S. (2014). Distribusi Logam Berat di Perairan Natuna.Jurnal IImu dan Teknologi Kelautan Tropis, Vol. 6 (2): 297-310. 
